РЕЦЕНЗІї, ІНФОРМАЦИЯ

Chornomors'ka

ISSN 2519-2523 (print) mynuushyna. - 2019. - No.14.

DOI: $10.18524 / 2519-2523.2019 .14 .187140$

УДК 94(477)

\title{
TO THE QUESTION ABOUT THE LOCALIZATION OF THE PLACES AND THE CELEBRATION OF THE MEMORY OF THE VICTORIES OF THE TROOPS OF SEMEN PALII ON THE TERRITORY OF MODERN ODESA REGION
}

\author{
Taras Honcharuk \\ ORCID: https://orcid.org/0000-0002-0119-0227 \\ DSc (History), Professor \\ Odessa I.I. Mechnikov National University \\ 2, Dvoryanska Str., Odessa, 65082, Ukraine \\ tarasiy2004@ukr.net
}

The problem of the localization of places of Cossack military operations of the XVI - XVIII centuries on the territory of modern Odesa region is discussed in this article. The difficulty of the determining the exact location of the battles according to the hydronyms mentioned in the documents is indicated. The author also proves the reasonableness of the location of the memorials erected on the places of the victories of the Cossacks led by the Fastovskyi colonel Semen Palii on the Kodyma River 1693 and on the modern Odesa region-Peresyp 1691. In the first case, due to the fact that the Kodyma battle was quite large and covered a huge territory, in the second - due to the ability to exactly localize the place of events. The failure of the attempts to search the "Peresyp", on which S. Palii won the victory, outside of modern Odesa, is revealed. The necessity of erecting the memorials in the honor of other victories of S. Paliy, such as, in the Udobnoe village of Belgorod-Dniester district of Odesa region, is underlined.

Keywords: S. Palii, the Cossacks victories, the history of Odesa region.

Тарас Гончарук

ORCID: https://orcid.org/0000-0002-0119-0227

Доктор історичних наук, професор

Одеський національний університет імені I.I. Мечникова

Вум. Дворянська, 2, Одеса, 65082, Україна tarasiy2004@ukr.net

\section{ДО ПИТАННЯ ПРО АОКААІЗАЦІЮ МІСЦЬ ТА ВІДЗНАЧЕННЯ ПАМ'ЯТІ ПЕРЕМОГ ВІЙСЬК СЕМЕНА ПАМІЯ НА ТЕРИТОРІї СУЧАСНОї ОДЕЩИНИ}

В статті розглядаеться проблема локалізаиії місиь козацьких військових операцій XVI - XVIII cm. на території сучасної Одещини. Вказуеться на складність визначення точного місия боїв за вказаними в документах гідронімами. Доводиться, обтрунтованість розташування встановлених 
пам'ятних знаків на місиях перемог козаків під проводом фастівського полковника Семена Палія на річиі Кодима 1693 р. та теперішньому одеському районі Пересип 1691 р. В першому випадку через те, ило битва на Кодимі була досить масштабною та охоплювала значну територію, $в$ другому - через можливість досить точно локалізувати місие подій. Розкривається безпідставність спроб шукати "Пересип", на якому здобув свою перемогу С. Палій, поза межами теперішньої Одеси. Наголошується на необхідності встановлення пам'ятних знаків на честь інших перемог С. Палія, зокрема, в селі Удобному Білгород-Дністровсъкого району Одесъкої області.

ключові слова: С. Палій, козаиькі перемоги, історія Одешини.

Позначення місць визначних козацьких перемог меморіальними знаками $є$ важливою складовою збереження історичної пам'яті українського народу. Це безперечно може стосуватися й теренів сучасної Одеської області, на яких помітні військові операції українського козацтва мали місце від першої писемної згадки про нього (1489 р. в хроніці Мартина Бєльського на теренах сучасного Савранського району Одещини) i до середини XIX ст. Проте часто виникає проблема максимально точного визначення місця тієї чи іншої військової події. Це, зокрема, стосується часів, коми терени сучасної Одещини були малозаселеними й в історичних документах часто не могмо було бути прив'язки до конкретних пунктів (місця боїв часто вказувалися як: "в полях за Очаковом", "на Бікгородщині", "у Буджаку" та ін.).

Тоді ж нерідко місця військових операцій також прив'язувалися до гідрографічних об’єктів, зокрема, річок. Наприклад, барський староста Бернард Претвич з козаками у 1540-х - 1550-х рр. громив татар на річках Барабой та Чичиклія [19], а кошовий Іван Сірко у 1665 та 1672 рр. - на річках Куяльниках (місця трьох бойових епізодів під керівництвом вказаного кошового в джерелах вказані як: "на Куяльниках", "за Куяльничком" та "на Куяльнику річці") [1; 3]. В перших випадках йдеться про річку Барабой завдовжки 71 км на теренах теперішніх Роздільнянського, Біляївського та Овідіопольського районів Одещини та річку Чичиклія завдовжки 156 км на теренах теперішніх Һюбашівського і Миколаївського районів Одеської області та Врадіївського і Веселинівського районів Миколаївської області. В других випадках - про річки Вемикий, Середній та Малий Куямьники завдовжки відповідно 150, 53 та 89 км, що розташовані на території теперішніх Подільського, Ананьївського, Захарівського, Вемикомихаймівського, Ширяївського й Іванівського районів Одеської області. Виходячи з невеликих масштабів вказаних військових подій (у разі дій Б. Претвича - наскоків на татарські орди, а вразі дій I. Сірка - пошуків неприятеля, успішного прориву через ворожій фронт та захоплення важливого татарського бранця), мокалізувати їхні точні місця за вказаними в документах гідронімами дия встановлення відповідних пам'ятних знаків навряд чи можмиво.

Попри вказані скмаднощі в останні роки на Одещині мали місце приклади досить вдалого вшанування місць козацьких перемог пам'ятними знаками. В цій публікації ми розглянемо ті 3 них, що 
стосувалися звитяжних боїв фастівського полковника Семена Палія. Передусім слід згадати кам'яний хрест на честь перемоги С. Палія над татарами на річці Кодимі 1693 р., який було урочисто відкрито 27 травня 2018 р. в селі Івашків Кодимського району. Як повідомляли 3МI: "Пам'ятний знак у вигляді хреста із 3-тонної кам'яної брили вцасноруч витесав скульптор Вцадислав І ьницький, який наразі проходить службу в мавах Збройних сим України" й на виготовлення вказаного знаку в скульптора пішло менше трьох тижнів [17]. Встановцення вказаного пам'ятного знаку мало в області досить широкий резонанс [8; 12].

Битва С. Палія 3 татарською ордою на р. Кодимі ("долині Кодимі") 1693 р. досить детально висвітлена в козацькому мітописі С. Величка [7], ій також присвячено чимало науково-популярних публікацій [4]. Річка Кодима, як і згадані вище інші річки Одещини, також $є$ чималим гідрографічним об'єктом. Вона має довжину 149 км. й розташована на теренах Кодимського, Балтського і Һюбашівського районів Одеської області та Кривоозерського і Первомайського районів Миколаївської області. Однак масштаби битви на Кодимі також були чималими. 3 одного боку, в ньому взяли участь кримська, ногайська та білгородська орди, з іншого - війська козаків з Правобережжя С. Палія та надіслані гетьманом Іваном Мазепою з Аівобережжя реєстровий та компанійський полки. Бій тривав два дні, під час яких війська супротивників неодноразово суттєво змінювали своє розташування (зокрема, С. Палій вночі здійснив кардинальну передислокацію своїх військ, щоб ввести в оману ворога) [5].

Виходячи з цього, з великою ймовірністю можна стверджувати, що місце розташування пам'ятного кам'яного хреста в с. Івашків, так чи інакше, з подіями славнозвісної битви на Кодимі пов'язано. Досить вдалим нам здається i вміщення у надписі на хресті, за пропозицією декана історичного факультету ОНУ імені I.I. Мечникова В'ячеслава Кушніра, підписаної цитати з миста гетьмана I. Мазепи 1693 р.: "...на урочищі Кодимі почали вони бій... і не тільки себе оборонили, але i ï, поганців, багатьох побили й поранили" Іван Мазепа". Це сприятиме усуненню традиції протиставлення постатей I. Мазепи та С. Палія, що ії нав’язували українцям ще від імперських часів.

Інше позначене пам'ятним знаком місце перемоги С. Палія на Одещині, пов'язане з подією далеко менш масштабною, ніж битва на Кодимі. Йдеться про напад близько двох сотень кінних козаків на татарський обоз, що прямував через "Пересип" з Аккерману до Очакова 1691 р., під час якого було взято здобич, двох татарських "язиків" та випущено на волю чимало християнських бранців. Три документи про вказаний бій (Аист С. Палія до I. Мазепи, мист I. Мазепи до Москви та свідчення полоненого на Пересипу татарина Асмана) опублікував видатний досмідник історії Запорозького козацтва Дмитро Яворницький. У примітках до своєї публікації Д. Яворницький назвав цей "Пересип" "урочищем біля Дніпра", проте живучі тоді у Москві, він навряд чи мав можливість точно цокалізувати місця усіх подій з документів, що ним вперше публікувалися 
(та й не мав такої мети). Пізніше одеський дослідник історичної географії та картографії Федір Петрунь зв'язав згаданий 1691 р. Пересип з районом поблизу Качибея (Одеси), що у той час переживав часи занепаду, зазначаючи: "В кінці XVII ст. "Кучюбей" залишався "урочищем" (...). Палій в 1691 р. підстерігав татар "в Пересипе", про Качибій, однак, в своїй реляції навіть не згадує" [13].

Слід нагадати, що "пересипами" в Україні називають піщані коси, які відокремлюють мимани від моря. Найвідоміший в світі одеський Пересип вперше згадується в опублікованих польським істориком Тадеєм Чацьким у XIX ст. цитатах з документів 1442 р. В них йдеться про те, що поблизу місця, "де був та є невеликий порт Качибей" (тобто Одеса) з'явилася нова земля, що стала предметом юридичного сперечання, а саме - "пересипи", що "за сто років були принесені морем від інших земель" [14]. Звертаємо увагу, що теперішній одеський пересип тоді звався "пересипами", бо це насправді два пересипу - пересипи Хаджибеївського та Куяльницького миманів, що згодом були об'єднані однією назвою. Це важлива особливість, про яку ми згодом згадаємо. Одеський історик XIX ст. провідний дослідник історії Качибея (Одеси) Олексій Маркевич не мав сумнівів, що в документах знайдених Т. Чацьким йдеться саме про "Качибейський Пересип", тобто район сучасної Одеси [13].

Саме після появи вказаного Пересипу, а вірніше, як вже було згадано, двох пересипів, Качибей (Одеса) став важливим пунктом прибережних сухопутних комунікацій. 3 одного боку - дороги на Очаків та Крим, а 3 іншого - на Акерман та Стамбул з відгалуженням на Бендери. До появи Пересипу зазначені комунікації проходили навколо миманів, тому не обов'язково мали включати до себе Качибей. Саме тому від XVI до кінця XVII ст. Качибей став місцем регулярних нападів козаків на проїжджаючи турецькі та татарські каравани. Характерний приклад такого нападу відбувся 1676 р. коли 26 козаків з Полтавщини вирушили до "урочища, що зветься Кочубей, де різні межать дороги" й там "звичайним своїм способом" напали на проїжджаючих "з Криму на Білгородщину" татар [2]. Безперечно до таких місць, "де різні межать дороги" належав і Пересип біля Качибея. Як видно на опублікованій сучасним дослідником історії фортифікації краю XVI - XVIII ст. Андрієм Красножоном мапі останньої чверті XVIII ст. на Пересипу сходилися: зі східного боку дороги, що прямували до Очакова i Криму через верхів'я Тилігулу та вздовж берега моря, а із західного - ті, що прямували на Бендери та Аккерман [15]. Не дивно, що, як свідчать опубліковані сучасним дослідником історії Гетьманщини В'ячеславом Станіславським документи, козацький ватажок Іван Ковальчук, який успішно напав на проїжджаючих біля Качибея татар 1689 р. (вочевидь, це була "зона діяльності" саме його ватаги) вже наступного 1690 року ще успішніше здійснив це на Пересип [16](свого часу ми знайомили одеську публіку з цим цікавим історичним відкриттям [9]). Тому цілком могічним й навіть неоригінальним був вибір Пересипу, як місця нападу на татар, С. Палієм 1691 p.

Принаймні від часів вказаної публікації Ф. Петруня в наукових та краєзнавчих колах Одеси про перемогу С. Палія на місцево Пересипу 
знали. Проте процес широкої популяризації цього знання серед громадськості міста відбувся вже в Незалежній Україні. Ми певною мірою домучимися до цього процесу газетними публікаціями [11] та реконструкцією подій бою 1691 р. в наукових виданнях [10]. Проте найбільший резонанс, на нашу думку, мало встановцення 2007 р. в одеському районі Аузанівка, що в безпосередній близькості від району Пересипу, великого дерев'яного хреста з інформацією про перемогу С. Палія. Організатором цього встановмення був керівник Чорноморського гайдамацького з'єднання, історик та громадський діяч Сергій Гуцалюк. Хрест став місцем щорічних громадських заходів до річниць вказаної козацької перемоги. Також в рамках декомунізації 2016 р. одна з прилеглих до пам'ятного місця вулиць була перейменована на вулицю С. Палія.

Однак не так давно дослідник історії Палеоліту Ігор Сапожніков вирішив заперечити мокалізацію вказаного бою на одеському Пересипу. Він "переніс" перемогу С. Палія на "пересип" Тимігульского миману (мало, хто у нас знає про існування цього "пересипу"). Притому зробив це, спираючись на низку дивних аргументів: стверджуючи, що цитати про "пересипи" у праці Т. Чацького не стосуються окомиць Качибею (чомусь не подавши повний текст цитати зі згадкою Качибею, так само як і не вказавши точку зору щодо цього О. Маркевича); надто довіряючи мокалізації місця бою Д. Яворницьким; подаючи явно непропорційний план Пересипу кінця XVIII ст. (за наявності багатьох набагато кращих планів, де чітко показано розгалужену транспортну мережу пов'язану 3 цим районом); натякаючи, що Ф. Петрунь ніби сумнівався в тому, що згаданий 1691 р. Пересип розташовувався біля Качибея (Одеси) та ін. До своєї публікації вказаний автор невідомо дия чого додав репубцікацію згаданого миста 1691 р. до Москви І. Мазепи про перемогу С. Палія [18] (хоча не так давно він нами републіковувався двічі - у виданнях 1999 та 2000 рр.). Проте І. Сапожніковим чомусь не було репубціковано вищезгадані свідчення полоненого татарина Асмана та $и$ ст самого C. Палія до I. Мазепи й (попри цитування в статті) недостатньо усвідомлено їхній зміст. А вони, між іншим, мають цінні відомості дия мокалізації місця подій. Не мише про те, що татари зазнали козацького удару "перейшовши Кочубей та інші небезпечні місця", але про те, що С. Палій, за словами Асмана, напав на супротивника "несподівано, 3 боку ударивши" [20]. Враховуючи свідчення 3 миста С. Палія, що він переміг ворога, "вдаривши на самому Пересипу" [20], можемо констатувати, що в нашому краї мише на одеському Пересипу це можна бумо зробити "з боку ударивши" (тобто з північного боку на татарський обоз, що рухався вздовж моря зі заходу на схід). Бо, як було вже сказано, одеський Пересип це по суті два пересипу - Хаджибейський та Куямьницький і мише тут можна було вразити ворога пройшовши між миманами, що С. Палій і зробив (на Тимігульському "пересипу" у XVII ст. це можна було здійснити хіба що на човнах). Ми могли б навести чимало інших аргументів, що Пересип, на якому розбив татар 1691 р. С. Пахій, саме той одеський Пересип, який знає цімий світ. Але, здається, і цього достатньо. 
На місці вищезгаданої перемоги С. Памія на одеському Пересипу, на нашу думку, з часом варто поставити і кам'яний хрест на кшталт того, який поставлено в с. Івашків Кодимського району (i в надпису на ньому також можна було б використати цитату з миста І. Мазепи). Звичайно, потребують увічнення пам'ятними знаками й інші місця перемог козаків фастівського полковника С. Палія на теренах сучасної Одещини. В першу чергу, на нашу думку, це треба зробити в с. Удобном Бікгород-Дністровського району, що в XVII ст. мало назву Ханкішиа (також Ганкушлі, або "село Ханське»). Тут С. Палій здобув перемогу над татарами 1694 р., за яку отримав привітання від польського короля Ян III Собеського та коронного гетьмана Станіслава Яблонського (детальна інформація про цю перемогу вже популяризувалася в методичні мітературі для вчителів краю, проте монументальне ії підкріплення б ніяк не завадимо [6]). Такі пам'ятні знаки є важливими для поглиблення історичної пам'яті населення нашого Південної України щодо подій доімперського козацького періоду іiі історії. I звичайно, їхньому встановленню мають передувати грунтовні та неупереджені дослідження істориків-фахівців щодо мокалізації місць подій.

\section{Джерема та мітература:}

1. Акты относящиеся к истории Южной и Западной России. - СПб., 1878. - Т. 9. C. $647,894-895$.

2. Акты, относящиеся к истории Южной и Западной России, собранные и изданные Археографической комиссией. - СПб., 1882. - Т. 12. - С. 637-638.

3. Акты, относящиеся к истории Южной и Западной Руси. - СПб., 1869. - Т. 6. C. 33-35.

4. Бачинский А.Д. Семен Палий. Битва на Кодыме // Бачинский А.Д., ДоброАюбский А.О., Новицкий Е.Ю. Книги дмя чтения по истории Одесщины дмя учащихся средних школ и средних специальньх учебньх заведений. Вьп. 1. - Котовск, 1992. C. 53-55.

5. Бачинська О.А., Гончарук Т.Г. Визначні українські козаки в історії Одеси та Одещини XVI - XIX ст.: Методичний посібник. - Одеса, 2009. - С. 36-38.

6. Бачинська О.А., Гончарук Т.Г. Визначні українські козаки в історії Одеси та Одешини XVI - XIX ст. (видання друге): Методичний посібник. - Одеса, 2019. C. 39.

7. Величко С.В. Аітопис. Т.2. - К., 1991. - С. 426-428.

8. Воронков В. Козацький хрест нагадає про перемогу на Кодимі [Електронний ресурс] // Голос України. - 2018. - 31 травня. - Режим доступу: http://www.golos.com.ua/article/303580

9. Гончарук Т. Одеський Пересип - місце козацької смави // Чорноморські новини. $-2012 .-26$ травня.

10. Гончарук Т.Г. Розді^ I. Запорозьке козацтво та Хаджибей (Одеса). Середина XV - 1775 рік // Одеса козацька. Наукові нариси. - Одеса: Фенікс, 2008. - С. 16 - 17.

11. Гончарук Т. Семен Палій на Пресипу // Думська площа. - 2000. - 25 серпня.

12. І трипікьська хата, і козацький хрест // Чорноморські новини. - 2018. 2 червня.

13. Історія Хаджибея (Одеси) в працях дослідників XIX-XX ст. Хрестоматія. / упор. Гончарук Т. Г. - Одеса: Екологія, 2015. - С. 78; 150.

14. Історія Хаджибея (Одеси) 1415-1795 рр. в документах / за ред. Т.Г. Гончарука. - Одеса: Астропринт, 2000. - С. 11. 
15. Красножон А. Фортеці та міста Північно-Західного Причорномор'я (XVXVIII ст.). Одеса: Чорномор'я, 2018. - С. 186.

16. Аисти Івана Мазепи. / упор. Станіславський В. - Т. I: 1687-1691. - К. : Інститут історії України НАНУ, 2002. - С. 387-388.

17. На Одещині на честь переможної битви козаків на річці Кодима встановили пам'ятний знак [Електронний ресурс] // День. - 2018. - 28 травня. - Режим доступу: https://day.kyiv.ua/uk/news/280518-na-odeshchyni-na-chestperemozhnoyi-bytvy-kozakiv-na-richci-kodyma-vstanovyly-pamyatnyy

18. Сапожников І.В. Місце двох боїв козаків з татарами поблизу Очакова (у 1690 та 1691 роках) // Наукові праці історичного факультету Запорізького національного університету. - 2015. - Вип. 44. - Том 1. - С. 41-48.

19. Український степовий кордон в середини ХУІ століття (Спогади барського старости Бернарда Претвича) // Старожитності Південної України. - ЗапоріжжяКиїв. - 1997. - Вип. 2. - С. 44, 51, 54-56.

20. Эварницкий И.Д. Источники дмя истории запорожских казаков. - Вмадимир, 1908. - T. 1. - C. 293; 304-305.

\section{References:}

1. Akty otnosyashchiyesya k istorii Yuzhnoy i Zapadnoy Rossii. SPb., 1878. T. 9. S. 647, 894895.

2. Akty otnosyashchiyesya $\mathrm{k}$ istorii Yuzhnoy i Zapadnoy Rossii. sobrannyye i izdannyye Arkheograficheskoy komissiyey. SPb., 1882. T. 12. S. 637-638.

3. Akty. otnosyashchiyesya $\mathrm{k}$ istorii Yuzhnoy i Zapadnoy Rusi. - SPb., 1869. - T. 6. S. 33-35.

4. Bachinskiy A.D. Semen Paliy. Bitva na Kodyme: Bachinskiy A.D., Dobrolyubskiy A.O., Novitskiy E.Yu. Knigi dlya chteniya po istorii Odesshchiny dlya uchashchikhsya srednikh shkol i srednikh spetsialnykh uchebnykh zavedeniy. Vyp.1. Kotovsk. 1992. S. 53-55.

5. Bachynska O.A., Honcharuk T.H. Vyznachni ukrainski kozaky v istorii Odesy ta Odeshchyny XVI - XIX st.: Metodychnyi posibnyk. Odesa, 2009. S. 36-38.

6. Bachynska O.A, Honcharuk T.H. Vyznachni ukrainski kozaky v istorii Odesy ta Odeshchyny XVI - KhIKh st. (vydannia druhe): Metodychnyi posibnyk. Odesa, 2019. S. 39.

7. Velychko S.V. Litopys. T. 2. K., 1991. S. 426-428.

8. Voronkov V. Kozatskyi khrest nahadaie pro peremohu na Kodymi [Elektronnyi resurs]: Holos Ukrainy. 2018. 31 travnia. Rezhym dostupu: http://www.golos.com.ua/article/303580

9. Honcharuk T. Odeskyi Peresyp - mistse kozatskoi slavy:Chornomorski novyny. 2012. 26 travnia.

10. Honcharuk T.H. Rozdil I. Zaporozke kozatstvo ta Khadzhybei (Odesa). Seredyna XV - 1775 rik: Odesa kozatska. Naukovi narysy. Odesa: Feniks, 2008. S. $16-17$.

11. Honcharuk T. Semen Palii na Presypu: Dumska ploshcha. 2000. 25 serpnia.

12. I trypilska khata, i kozatskyi khrest: Chornomorski novyny. 2018. 2 chervnia.

13. Istoriia Khadzhybeia (Odesy) $\mathrm{v}$ pratsiakh doslidnykiv KhIKh-KhKh st. Khrestomatiia. upor. Honcharuk T. H. Odesa: Ekolohiia, 2015. S. 78; 150.

14. Istoriia Khadzhybeia (Odesy) 1415-1795 rr. v dokumentakh / za red. T.H. Honcharuka.. Odesa: Astroprynt, 2000. S. 11.

15. Krasnozhon A. Fortetsi ta mista Pivnichno-Zakhidnoho Prychornomoria (XVXVIII st.). Odesa: Chornomoria, 2018. S. 186.

16. Lysty Ivana Mazepy / upor. Stanislavskyi V. T. I: 1687-1691. K.: Instytut istorii Ukrainy NANU, 2002. S. 387-388. 
17. Na Odeshchyni na chest peremozhnoi bytvy kozakiv na richtsi Kodyma vstanovyly pamiatnyi znak [Elektronnyi resurs]: Den. 2018. 28 travnia. Rezhym dostupu: https://day.kyiv.ua/uk/news/280518-na-odeshchyni-na-chest-peremozhnoyi-bytvykozakiv-na-richci-kodyma-vstanovyly-pamyatnyy

18. Sapozhnykov I.V. Mistse dvokh boiv kozakiv z tataramy poblyzu Ochakova (u 1690 ta 1691 rokakh): Naukovi pratsi istorychnoho fakultetu Zaporizkoho natsionalnoho universytetu. 2015. Vyp. 44. Tom 1. S. 41-48.

19. Ukrainskyi stepovyi kordon $\mathrm{v}$ seredyny KhUI stolittia (Spohady barskoho starosty Bernarda Pretvycha): Starozhytnosti Pivdennoi Ukrainy. Zaporizhzhia-Kyiv. 1997. Vyp. 2. - S.44, 51, 54-56.

20. Evarnitskiy I.D. Istochniki dlya istorii zaporozhskikh kazakov. Vladimir. 1908. T. 1. S. 293; 304-305.

Tарас Гончарук

ORCID: https://orcid.org/0000-0002-0119-0227 Доктор исторических наук, профессор Одесский национальный университет имени И.И. Мечникова УА. Дворянская, 2, Одесса, 65082, Украина tarasiy2004@ukr.net

\section{К вопросу о локализаиии мест и празднованию памяти побед войск Семена Палия на территории современной Одесской области}

В статье рассматривается проблема локализаиии мест казаиких военных операций XVI - XVIII вв. на территории современной Одесской области. Указывается на сложность определения точного места боев по указанньм в документах гидронимам. Доказывается, обоснованность расположения установленных памятных знаков на местах побед казаков под предводительством фастовского полковника Семена Палия на реке Кодыма 1693 г. и нынешнем одесском районе Пересыпь 1691 г. В первом случае из-за того, ито битва на Кодыме была довольно масштабной и охватывала значительную территорию, во втором - из-за возможности достаточно точно локализовать место событий. Раскрывается несостоятельность попыток искать "Пересыпь", на которой одержал свою победу С. Палий, вне нынешней Одессы. Подчеркивается необходимость установления памятных знаков в честь других побед С. Палия, в частности, в селе Удобном БелгородДнестровского района Одесской области.

ключевые слова: С. Палий, казаикие победы, история Одесской области.

Отримано: 14.12.2019p. 